University of Nebraska - Lincoln

DigitalCommons@University of Nebraska - Lincoln

Faculty Publications, Department of Psychology

Psychology, Department of

2019

\title{
A Systematic Review of Genetic Influence on Psychological Resilience
}

\author{
Kosuke Niitsu \\ University of Colorado Anschutz Medical Campus, kosuke.niitsu@cuanschutz.edu \\ Michael J. Rice \\ University of Colorado Anschutz Medical Campus, michael.j.rice@cuanschutz.edu \\ Julia F. Houfek \\ University of Nebraska Medical Center, jhoufek@unmc.edu \\ Scott F. Stoltenberg \\ University of Nebraska-Lincoln, sstoltenberg2@unl.edu \\ Kevin A. Kupzyk \\ University of Nebraska Medical Center, kevin.kupzyk@unmc.edu
}

See next page for additional authors

Follow this and additional works at: https://digitalcommons.unl.edu/psychfacpub

Part of the Genetics and Genomics Commons, and the Psychology Commons

Niitsu, Kosuke; Rice, Michael J.; Houfek, Julia F.; Stoltenberg, Scott F.; Kupzyk, Kevin A.; and Barron, Cecilia R., "A Systematic Review of Genetic Influence on Psychological Resilience" (2019). Faculty Publications, Department of Psychology. 945.

https://digitalcommons.unl.edu/psychfacpub/945

This Article is brought to you for free and open access by the Psychology, Department of at DigitalCommons@University of Nebraska - Lincoln. It has been accepted for inclusion in Faculty Publications, Department of Psychology by an authorized administrator of DigitalCommons@University of Nebraska - Lincoln. 


\section{Authors}

Kosuke Niitsu, Michael J. Rice, Julia F. Houfek, Scott F. Stoltenberg, Kevin A. Kupzyk, and Cecilia R. Barron 
Published in Biological Research for Nursing 21:1 (2019), pp. 61-71; doi: 10.1177/1099800418800396 Copyright (C) 2018 Kosuke Niitsu, Michael J. Rice, Julia F. Houfek, Scott F. Stoltenberg, Kevin A. Kupzyk, and Cecilia R. Barron. Published by SAGE. Used by permission.

Published online September 17, 2018.

\title{
A Systematic Review of Genetic Influence on Psychological Resilience
}

\author{
Kosuke Niitsu, PhD, APN, PMHNP-BC, ${ }^{1}$ \\ Michael J. Rice, PhD, APN, FAAN, ${ }^{1}$ Julia F. Houfek, PhD, APRN-CNS, ${ }^{2}$ \\ Scott F. Stoltenberg, PhD, ${ }^{3}$ Kevin A. Kupzyk, PhD, ${ }^{2}$ \\ and Cecilia R. Barron, PhD, $\mathrm{RN}^{2}$
}

1. College of Nursing, University of Colorado Anschutz Medical Campus, Aurora, Colorado, USA

2. College of Nursing, University of Nebraska Medical Center, Omaha, Nebraska, USA

3. Department of Psychology, University of Nebraska-Lincoln, Lincoln, Nebraska, USA

Corresponding author - Kosuke Niitsu, College of Nursing, University of Colorado Anschutz Medical Campus, 13120 E 19th Ave. C288-19, Education 2 North, Room 4228, Aurora, CO 80045, USA, email kosuke.niitsu@ucdenver.edu

\begin{abstract}
When exposed to adversity, some individuals are at an increased risk of posttraumatic stress disorder, experiencing persistent biopsychosocial disturbances, whereas others adapt well, described as resilience. Resilience is a complex biopsychosocial phenomenon conceptualized as adaptation to adversity influenced by an individual's genetic variants, epistasis, epigenetics, and gene-by-environment interactions. Studies on psychological resilience have focused on behavioral and psychosocial variables with far less examination of the genetic contributions. The purpose of this review is to identify specific genetic variants contributing to the biological capacity for psychological resilience. PubMed and PsycINFO were searched using the following key words: psychological resilience AND genotype(s). Additional articles were identified from the Human Genome Epidemiology Navigator using the term resilience, psychological. Ten studies met the criteria. Six genes were empirically associated with psychological resilience: serotonin-transporter-linked polymorphic region (5-HTTLPR), dopamine receptor $\mathrm{D} 4$, brain-derived neurotrophic factor $(B D N F)$, corticotropin-releasing hormone receptor 1 ,
\end{abstract}


oxytocin receptor and regulator of G-protein signaling 2. The findings of this systematic review suggest that the $\mathrm{L} / \mathrm{L}$ or $\mathrm{L}^{\prime} / \mathrm{L}^{\prime}$ genotype of 5-HTTLPR and rs25531 in children/adolescents and the $\mathrm{S} / \mathrm{S}$ or $\mathrm{S}^{\prime} / \mathrm{S}^{\prime}$ genotype in adults are most frequently related to resilience. Additionally, the $\mathrm{Val} / \mathrm{Val}$ genotype of rs6265 in BDNF in Caucasians was also associated with resilience. There are numerous factors contributing to the complexity of determining the genetic influence on resilience including analysis of rs25531, assumptions of the mode of inheritance, operationalization of resilience, demographic and population characteristics, sample size, and other types of genetic influence including epistasis and epigenetics. While current evidence is supportive, further investigation of the genetic influence on resilience is required.

Keywords: psychological resilience, genetics, genotype, systematic review, gene-by-environment interaction, adversity

Resilience is the process of sustaining or strengthening physiological or behavioral stability in response to stressors. This view maintains that resilience is an endogenous system responsible for maintaining the functional stability of an organism. This system maintains the stability by employing variable genetic, physiologic, and psychological responses to stressors on the organism (Feder, Nestler, \& Charney, 2009). Resilience requires the presence of a stressful event (Bonanno, 2012). Therefore, "it is meaningless to assess resilience in the absence of adversity" (Mancini \& Bonanno, 2010, p. 259). The term resilience differs from ego-resiliency, which is a personality characteristic of the individual and does not presuppose exposure to adversity (Luthar, Cicchetti, \& Becker, 2000; Niitsu et al., 2017).

Most individuals experience at least one adverse event, such as a natural disaster, in their lifetime (Benjet et al., 2016). When exposed to such an event, some individuals experience biopsychosocial disturbances, such as negative changes in mood and cognition, and are at increased risk of posttraumatic stress disorder (PTSD; American Psychiatric Association, 2013). Yet, despite the high frequency of exposure to traumatic events, the prevalence of PTSD is low (Karam et al., 2014). This low rate suggests that there are multiple patterns of psychological responses to adverse events, with PTSD being only one form of response (Bonanno \& Diminich, 2013; Yehuda et al., 2015). Resilience, an adaptive psychological reaction to adversity, is another possible response. There are even people who experience psychological growth because of a traumatic experience (Tedeschi \& Calhoun, 2004). By identifying genetic influences on resilience, we may be better able to investigate how inheritance contributes to psychological adaptation to adverse events.

Numerous factors contribute to psychological resilience (Bonanno, Galea, Bucciarelli, \& Vlahov, 2007; Southwick, Bonanno, Masten, Panter-Brick, \& Yehuda, 2014). According to the society-to-cells resilience framework defined by Szanton and Gill (2010), factors influencing resilience are broadly categorized into 6 domains: (1) society, (2) community, (3) family, (4) individual, (5) physiological, and (6) cellular. Because the study of resilience is an emerging science, much remains to be discovered, particularly about physiological and cellular contributions (Cicchetti, 2010; Walker, Pfingst, Carnevali, Sgoifo, \& Nalivaiko, 2017).

Neurochemical, neuroendocrine, and neural systems are all activated in response to stressful situations (Feder et al., 2009). These biological processes shape the functioning of the neural circuits that regulate emotion reactivity, fear, reward, and social behavior and 
influence resilience. For example, serotonin, a monoamine neurotransmitter, regulates appetite, sleep, and feelings of well-being while simultaneously affecting mood and anxiety (Osorio, Probert, Jones, Young, \& Robbins, 2016). The serotonin transporter regulates serotonergic neurotransmission by removing serotonin released into the synaptic cleft (Canli $\&$ Lesch, 2007). Molecular studies indicate that the short (S) serotonin-transporter-linked polymorphic region (5-HTTLPR) variant of the SLC6A4 gene produces significantly less serotonin transporter messenger RNA than the long (L) variant (Lesch et al., 1996). This finding suggests that individuals with the $L$ variant of 5-HTTLPR may have higher concentrations of serotonin in the synaptic cleft than those with the $S$ variant (Canli \& Lesch, 2007; Lesch et al., 1996). Accordingly, genetic variations in the serotonergic system may explain variations in the level of psychological resilience (Osorio et al., 2016). Collectively, genetic variations in the serotonergic system along with those in the dopaminergic and noradrenergic systems and the hypothalamic-pituitary-adrenal (HPA) axis are hypothesized to form an individual's genetic capacity for psychological resilience (Wu et al., 2013).

When exploring genetic effects on the behavioral dimensions of resilience, investigators also need to consider the role environment plays as a potent source for promoting resilience (Rende, 2012). Both "nature" (genetics) and "nurture" (environment) contribute to behavioral differences among individuals through the developmental process of genotype-environment correlation and interaction (Plomin, Owen, \& McGuffin, 1994). There are three main categories of interplay between genes and environment that impact the development of a phenotype (i.e., an observable characteristic): (1) main effects, (2) gene-environment correlation, and (3) gene-by-environment ( $\mathrm{G} \times \mathrm{E}$ ) interaction (Pluess \& Meaney, 2015). Main effects describe the direct associations between genes and phenotype or between environment and phenotype. Gene-environment correlation refers to instances in which genetic factors increase the probability of specific environmental exposures. $G \times E$ interaction refers to genetic (or environmental) effects on a phenotype that are moderated by environmental (or genetic) factors. In the present review, the phenotype of interest is psychological resilience. Because resilience requires exposure to at least one adverse environmental stimulus by definition, we selected only resilience studies that investigated $G \times E$ interactions to include.

In psychiatric research, the outcome of $G \times E$ interactions is often conceptualized as some form of negative reaction to adversity, such as PTSD (Caspi \& Moffitt, 2006). Yet the concept of psychological resilience cannot be narrowly defined as an absence of a psychopathological response (Almedom \& Glandon, 2007). It is essential to assess not only the negative outcomes but also the positive mental health outcomes that may be associated with exposure to adverse events (Niitsu et al., 2017). Researchers can evaluate positive mental health outcomes using a series of instruments (Pangallo, Zibarras, Lewis, \& Flaxman, 2015), such as the Connor-Davidson Resilience Scale (Connor \& Davidson, 2003) and the posttraumatic growth (PTG) Inventory (Tedeschi \& Calhoun, 1996). Psychological resilience in terms of $G \times E$ interactions is often conceptualized as reactivity to adversity (Davydov, Stewart, Ritchie, \& Chaudieu, 2010). If an individual with a certain genotype maintains or even improves their mental health in response to adversity, then this genotype can be described as contributing to resilience (Pluess, 2017). In the present review, we 
included studies measuring positive mental health responses following exposure to adverse events to identify genetic variants empirically associated with psychological resilience. Whereas there are multiple meta-analyses examining the relationships between genetic variants and specific disorders such as PTSD (Zhao et al., 2017), the field investigating the role of $\mathrm{G} \times \mathrm{E}$ interactions in psychological resilience is still emerging. Therefore, we broadened the scope of this review by defining resilience flexibly to include positive mental health outcomes. A better understanding of genetic variants that contribute to psychological resilience would be valuable for developing an individually tailored approach to foster resilience.

\section{Method}

We conducted this systematic review in July 2017, following the Preferred Reporting Items for Systematic Reviews and Meta-Analyses (PRISMA; Moher, Liberati, Tetzlaff, Altman, \& PRISMA Group, 2009) statement. We searched PubMed and PsycINFO for appropriate articles with the key words psychological resilience AND genotype(s) using medical subject headings (MeSH) terms (index list) in PubMed and Thesaurus in PsycINFO. In addition, we identified research articles associated with the term resilience, psychological in the Human Genome Epidemiology (HuGE) Navigator Phenopedia (Yu, Clyne, Khoury, \& Gwinn, 2010). We did not place any restrictions regarding year of publication because the genetic study of resilience is a relatively new area of study. Our inclusion criteria for articles to include in the review were (1) human subjects-approved research, (2) written in English, (3) published in a peer-reviewed journal as an original research article, (4) molecular genetic study, such as a candidate gene association study, (5) G $\times$ E interaction study, and (6) positive mental health outcomes measured. The exclusion criteria were (1) animal studies, (2) written in languages other than English, (3) non-peer-reviewed manuscripts and general review articles, (4) epigenetic or twin studies, (5) studies investigating only the main effects or the G-E correlation, and (6) only negative mental health outcomes measured.

\section{Results}

\section{Study Selection}

Figure 1 depicts the article search and selection process according to the PRISMA statement (Moher et al., 2009). Our initial search yielded 28 articles from PubMed, 8 articles from PsycINFO, and 23 articles from the HuGE Navigator Phenopedia, for a combined total of 59 articles. After removing 23 duplicates, we screened 36 studies for inclusion. We excluded six articles because they did not meet Inclusion Criteria 1-4, and we excluded 20 articles because they did not meet Inclusion Criteria 5-6. For example, we excluded Rana et al. (2014), which examined direct associations between individual single-nucleotide polymorphisms (SNPs) and resilience (did not meet Inclusion Criterion 5). Because resilience results from a dynamic interplay among negative environmental influences and multilevel factors that protect against stressors and promote positive adjustment, studies that measure resilience as an individual trait may be problematic (Kim-Cohen \& Turkewitz, 2012). We retained 10 research articles for further analyses. None of these 10 studies measured 
negative mental health outcomes (Exclusion Criterion 6). Table 1 summarizes the relevant findings of these 10 studies.

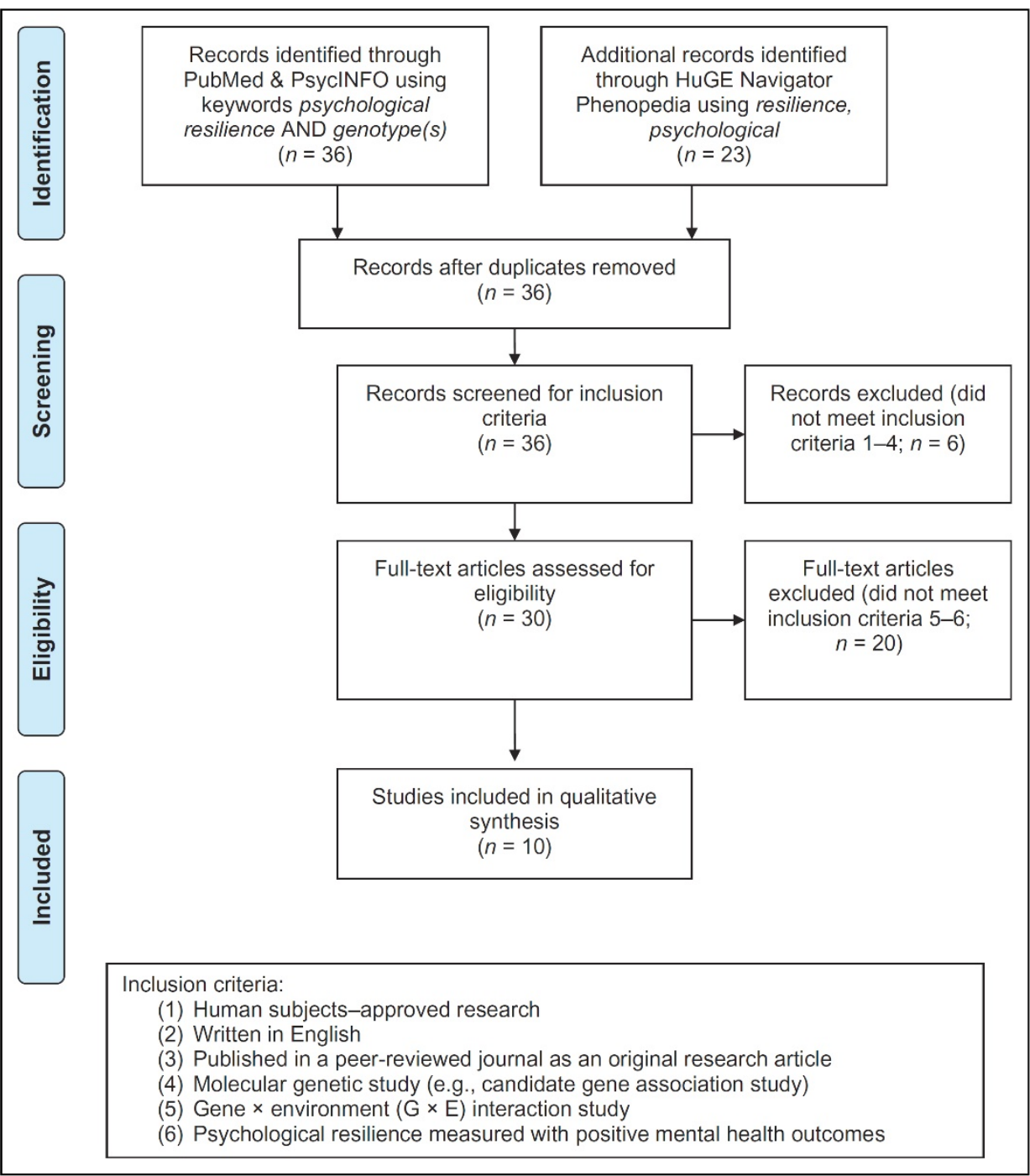

Figure 1. Search and selection procedure for a systematic review of genetic influence on psychological resilience using Preferred Reporting Items for Systematic Reviews and Meta-Analyses (PRISMA) guidelines. Adapted from Moher et al. (2009). 
Table 1. Summary of Reviewed Studies of Genetic Influence on Psychological Resilience

\begin{tabular}{|c|c|c|c|c|c|}
\hline $\begin{array}{l}\text { Author } \\
\text { (Year) }\end{array}$ & $\begin{array}{l}\text { Population } \\
\text { (N) }\end{array}$ & Polymorphism & Adversity & $\begin{array}{l}\text { Mental Health } \\
\text { Measure }\end{array}$ & Findings \\
\hline $\begin{array}{l}\text { Bradley } \\
\text { et al. } \\
(2013)\end{array}$ & $\begin{array}{l}\text { African } \\
\text { American } \\
\text { adults } \\
(N=971)\end{array}$ & $\begin{array}{l}\text { rs53576 in } \\
\text { OXTR }\end{array}$ & $\begin{array}{l}\text { Childhood } \\
\text { trauma, life- } \\
\text { time trauma } \\
\text { exposure }\end{array}$ & $\begin{array}{l}\text { CD-RISC, } \\
\text { PANAS }\end{array}$ & $\begin{array}{l}\text { Family environment } \\
\text { effects on combination } \\
\text { of resilient coping and } \\
\text { positive affect were } \\
\text { weaker among } \\
\text { individuals with the } \\
\text { A/A genotype of } \\
\text { rs53576 in OXTR than } \\
\text { among those with the } \\
\text { G/G and G/A geno- } \\
\text { types }\end{array}$ \\
\hline $\begin{array}{l}\text { Carli et al. } \\
\text { (2011) }\end{array}$ & $\begin{array}{l}\text { Male } \\
\text { prisoners in } \\
\text { Italy } \\
(N=763)\end{array}$ & 5-HTTLPR & $\begin{array}{l}\text { Childhood } \\
\text { adversities }\end{array}$ & CD-RISC & $\begin{array}{l}\text { Childhood adversities' } \\
\text { effects on resilience } \\
\text { were weaker among } \\
\text { male prisoners with } \\
\text { the S/S genotype of } \\
5-H T T L P R \text { than among } \\
\text { those with the L/L or } \\
\text { L/S genotypes }\end{array}$ \\
\hline $\begin{array}{l}\text { Cicchetti } \\
\text { and } \\
\text { Rogosch } \\
(2012)\end{array}$ & $\begin{array}{l}\text { Maltreated } \\
\text { and non- } \\
\text { maltreated } \\
\text { low-income } \\
\text { children } \\
(N=595)\end{array}$ & $\begin{array}{l}\text { 5-HTTLPR; } \\
\text { rs1800955 in } \\
\text { DRD4; rs53576 } \\
\text { in OXTR; } \\
\text { rs110402, } \\
\text { rs242924, and } \\
\text { rs7209436 in } \\
\text { CRHR1 }\end{array}$ & Maltreatment & $\begin{array}{l}\text { Resilient } \\
\text { functioning }\end{array}$ & $\begin{array}{l}\text { Maltreatment effects } \\
\text { on resilient functioning } \\
\text { were weaker among } \\
\text { children who carried } \\
\text { the following } \\
\text { genotypes: } \mathrm{L} / \mathrm{L} \text { of } \\
5 \text {-HTTLPR, C/C and } \\
\mathrm{C} / \mathrm{T} \text { of rs } 1800955 \text { in } \\
\text { DRD4, G/G of rs53576 } \\
\text { in OXTR; and } 1 \text { or } 2 \\
\text { copies of TAT } \\
\text { haplotype in } C R H R 1\end{array}$ \\
\hline $\begin{array}{l}\text { Das et al. } \\
(2011)\end{array}$ & $\begin{array}{l}\text { General } \\
\text { population } \\
\text { in Australia } \\
(N=1148)\end{array}$ & $\begin{array}{l}\text { VNTR in DRD4 } \\
\text { exon III }\end{array}$ & $\begin{array}{l}\text { Childhood } \\
\text { adversities }\end{array}$ & CD-RISC & $\begin{array}{l}\text { Childhood adversities' } \\
\text { effects on resilience } \\
\text { were weaker among } \\
\text { individuals with the } \\
7 \mathrm{r} / 7 \mathrm{r} \text { and } 7 \mathrm{r} / 4 \mathrm{r} \text { geno- } \\
\text { types in } D R D 4 \text { than } \\
\text { among those with the } \\
4 \mathrm{r} / 4 \mathrm{r} \text { genotype. }\end{array}$ \\
\hline $\begin{array}{l}\text { Dunn et al. } \\
\text { (2014) }\end{array}$ & $\begin{array}{l}\text { Low } \\
\text { income non- } \\
\text { Hispanic } \\
\text { Black } \\
\text { parents } \\
(N=205)\end{array}$ & rs4606 in RGS2 & $\begin{array}{l}\text { Hurricane } \\
\text { Katrina }\end{array}$ & $\begin{array}{l}\text { PTG } \\
\text { Inventory }\end{array}$ & $\begin{array}{l}\text { Hurricane exposure } \\
\text { effects on PTG were } \\
\text { stronger among Black } \\
\text { parents with the G/G } \\
\text { genotype of rs4606 in } \\
\text { RGS2 than among } \\
\text { those with the C/C } \\
\text { genotype (C/G was in- } \\
\text { termediate) }\end{array}$ \\
\hline
\end{tabular}


Nittsu et Al., BIOLOGICAL RESEARCH FOR NURSING 21 (2019)

Table 1, continued

\begin{tabular}{|c|c|c|c|c|c|}
\hline $\begin{array}{l}\text { Author } \\
\text { (Year) }\end{array}$ & $\begin{array}{l}\text { Population } \\
\text { (N) }\end{array}$ & Polymorphism & Adversity & $\begin{array}{l}\text { Mental Health } \\
\text { Measure }\end{array}$ & Findings \\
\hline $\begin{array}{l}\text { Graham } \\
\text { et al. } \\
\text { (2013) }\end{array}$ & $\begin{array}{l}\text { Veterans } \\
\text { with mild } \\
\text { TBI } \\
(n=41) \\
\text { and } \\
\text { without } \\
\text { TBI } \\
(n=26)\end{array}$ & $\begin{array}{l}\text { 5-HTTLPR and } \\
\text { rs25531 }\end{array}$ & $\begin{array}{l}\text { Perceived } \\
\text { limitations }\end{array}$ & CD-RISC & $\begin{array}{l}\text { Perceived limitations' } \\
\text { effects on resilience } \\
\text { were weaker among } \\
\text { veterans with } S^{\prime} / S^{\prime} \\
\text { genotype of } 5-H T T L P R \\
\text { and rs25531 than } \\
\text { among those with the } \\
\mathrm{L}^{\prime} / \mathrm{L}^{\prime} \text { and } \mathrm{L}^{\prime} / \mathrm{S}^{\prime} \\
\text { genotypes }\end{array}$ \\
\hline $\begin{array}{l}\text { Nederhof } \\
\text { et al. } \\
(2010)\end{array}$ & $\begin{array}{l}\text { Adolescents } \\
\text { in the } \\
\text { Nether- } \\
\text { lands } \\
(N=1,032)\end{array}$ & $\begin{array}{l}\text { 5-HTTLPR and } \\
\text { rs25531; rs6265 } \\
\text { in BDNF }\end{array}$ & $\begin{array}{l}\text { Childhood } \\
\text { adversities }\end{array}$ & $\begin{array}{l}\text { Effortful } \\
\text { control }\end{array}$ & $\begin{array}{l}\text { Childhood adversities' } \\
\text { effects on Effortful } \\
\text { Control were weaker } \\
\text { among Dutch } \\
\text { adolescents with the } \\
\mathrm{L}^{\prime} / \mathrm{L}^{\prime} \text { genotype of } \\
\text { 5-HTTLPR and rs } 25531 \\
\text { than among those with } \\
\text { the } \mathrm{S}^{\prime} / \mathrm{S}^{\prime} \text { and L'/S' } \\
\text { genotypes. Childhood } \\
\text { adversities effect on } \\
\text { effortful control was } \\
\text { weaker among Dutch } \\
\text { adolescents with the } \\
\text { Val/Val genotype of } \\
\text { rs6265 in BDNF than } \\
\text { those with the Met/Met } \\
\text { and Val/Met genotypes }\end{array}$ \\
\hline $\begin{array}{l}\text { Nikolova } \\
\text { et al. } \\
(2012)\end{array}$ & $\begin{array}{l}\text { Bulgarian } \\
\text { high school } \\
\text { students } \\
(N=70)\end{array}$ & $\begin{array}{l}\text { 5-HTTLPR and } \\
\text { rs25531 }\end{array}$ & $\begin{array}{l}\text { Naturalistic } \\
\text { stressor } \\
\text { (school } \\
\text { final } \\
\text { examinations) }\end{array}$ & $\begin{array}{l}\text { Reward } \\
\text { responsive- } \\
\text { ness }\end{array}$ & $\begin{array}{l}\text { A naturalistic stressor's } \\
\text { effects on reward } \\
\text { responsiveness were } \\
\text { weaker among males } \\
\text { with the } L^{\prime} / L^{\prime} \text { genotype } \\
\text { of } 5-H T T L P R \text { and } \\
\text { rs } 25531 \text { than among } \\
\text { those with the } S^{\prime} / S^{\prime} \text { and } \\
L^{\prime} / S^{\prime} \text { genotypes }\end{array}$ \\
\hline $\begin{array}{l}\text { Reinelt } \\
\text { et al. } \\
(2015)\end{array}$ & $\begin{array}{l}\text { General } \\
\text { population } \\
\text { in Germany } \\
(N=1,811)\end{array}$ & $\begin{array}{l}\text { 5-HTTLPR and } \\
\text { rs25531 }\end{array}$ & $\begin{array}{l}\text { (Lack of) } \\
\text { social support }\end{array}$ & RS; SOC & $\begin{array}{l}\text { Social support's } \\
\text { impacts on RS and } \\
\text { SOC were weaker } \\
\text { among individuals } \\
\text { with the } S^{\prime} / S^{\prime} \text { genotype } \\
\text { of } 5-H T T L P R \text { and } \\
\text { rs } 25531 \text { than among } \\
\text { those with the } L^{\prime} / L^{\prime} \\
\text { genotype }\left(\mathrm{L}^{\prime} / \mathrm{S}^{\prime} \text { was }\right. \\
\text { intermediate) }\end{array}$ \\
\hline
\end{tabular}


Table 1, continued

\begin{tabular}{|c|c|c|c|c|c|}
\hline $\begin{array}{l}\text { Author } \\
\text { (Year) }\end{array}$ & $\begin{array}{l}\text { Population } \\
\text { (N) }\end{array}$ & Polymorphism & Adversity & $\begin{array}{l}\text { Mental Health } \\
\text { Measure }\end{array}$ & Findings \\
\hline $\begin{array}{l}\text { van Winkel } \\
\text { et al. } \\
\text { (2014) }\end{array}$ & $\begin{array}{l}\text { Individuals } \\
\text { with } \\
\text { residual } \\
\text { depressive } \\
\text { sympto- } \\
\text { matology } \\
(n=130) \\
\text { and female } \\
\text { twins } \\
(n=621) \\
\text { in Belgium }\end{array}$ & rs6265 in $B D N F$ & Social stress & $\begin{array}{l}\text { Momentary } \\
\text { affective states } \\
\text { (negative and } \\
\text { positive affect) }\end{array}$ & $\begin{array}{l}\text { Social stress's effects } \\
\text { on negative affect } \\
\text { responses were weaker } \\
\text { among individuals } \\
\text { with the Val/Val } \\
\text { genotype of rs6265 in } \\
B D N F \text { than among } \\
\text { those with the Val/Met } \\
\text { genotype. Positive } \\
\text { emotions neutralized } \\
\text { the moderating effect } \\
\text { of genotypes of rs6265 } \\
\text { in } B D N F \text { on social- } \\
\text { stress sensitivity in a } \\
\text { dose-response fashion }\end{array}$ \\
\hline
\end{tabular}

Note: CD-RISC = Connor-Davidson Resilience Scale; 5-HTTLPR = serotonin-transporter-linked polymorphic region; PANAS = Positive and Negative Affect Scale; PTG = posttraumatic growth; RGS2 = regulator of G-protein signaling 2; RS = resilience scale; $\mathrm{SOC}=$ sense of coherence; $\mathrm{TBI}=$ traumatic brain injury; $\mathrm{VNTR}=$ variable number tandem repeat.

\section{Genetic Variations Associated with Resilience}

The 10 reviewed $\mathrm{G} \times \mathrm{E}$ interaction studies revealed six genes that were empirically associated with psychological resilience. Consistent with Wu et al.'s (2013) hypotheses, most of these genes are involved with the central nervous system: the serotonin-transporter-linked polymorphic region (5-HTTLPR) in SLC6A4, dopamine receptor D4 (DRD4), brain-derived neurotrophic factor $(B D N F)$, corticotropin-releasing hormone receptor 1 (CRHR1), oxytocin receptor (OXTR), and regulator of G-protein signaling 2 (RGS2). Table 2 includes descriptions of the functional importance of each gene.

Table 2. Description of Genes Empirically Associated with Psychological Resilience

\begin{tabular}{ll}
\hline CNS System and Gene & Description \\
\hline Serotonergic & The solute carrier family 6 member 4 (SLC6A4) gene encodes an inte- \\
5-HTTLPR in SLC6A4 & gral membrane protein that transports the neurotransmitter serotonin \\
from synaptic spaces into presynaptic neurons (National Center for \\
Biotechnology Information, 2017c). 5-HTTLPR is a variation in the reg- \\
ulatory region coding for the serotonin transporter (5-HTT), which re- \\
moves serotonin from the synaptic cleft (Canli \& Lesch, 2007). It is \\
composed of the short "S" and the long "L" versions so that the ex- \\
pression of the 5-HTT mRNA of the L allele is about three times higher \\
than that of the S allele (Heils et al., 1996). There is a single base sub- \\
stitution (A $>$ G) known as rs25531 (Hu et al., 2006), producing an “LG" \\
allele, which is functionally equivalent to the S allele (Wendland et al., \\
2006)
\end{tabular}


Table 2, continued

\begin{tabular}{|c|c|}
\hline CNS System and Gene & Description \\
\hline $\begin{array}{l}\text { Dopaminergic } \\
\text { DRD4 }\end{array}$ & $\begin{array}{l}\text { The DRD4 gene codes for the dopamine D4 receptor, which is most } \\
\text { expressed in specific areas of the brain including the frontal cortex and } \\
\text { amygdala (Murray et al., 1995). This gene contains a 48-bp sequence } \\
\text { (VNTR), which is repeated between } 2 \text { and } 11 \text { times, on its third exon } \\
\text { (Oak, Oldenhof, \& Van Tol, 2000). DRD4 molecules with seven repeats } \\
\text { are less efficient at inhibiting the enzyme adenylate cyclase compared } \\
\text { to those carrying four copies (Asghari et al., 1995; Jovanovic, Guan, \& } \\
\text { Van Tol, 1999). Additionally, a SNP in DRD4, rs1800955, describes } \\
-521 \text { C/T, which is a cytosine (C) to thymine (T) transition at base -521 } \\
\text { in the upstream promoter region (National Center for Biotechnology } \\
\text { Information, 2017b). The -521C form is associated with a 40\% increase } \\
\text { in DRD4 transcription in cultured cells (Okuyama et al., 2000) }\end{array}$ \\
\hline $\begin{array}{l}\text { BDNF } \\
\text { BDNF }\end{array}$ & $\begin{array}{l}\text { The BDNF gene encodes a member of the nerve growth factor family } \\
\text { of proteins, brain-derived neurotrophic factor (BDNF; National Center } \\
\text { for Biotechnology Information, 2017a). A SNP, rs6265, at nucleotide } \\
\text { 196(G/A) produces an amino acid substitution, valine to methionine, } \\
\text { at codon } 66 \text { (National Center for Biotechnology Information, 2017a), } \\
\text { leading to lower levels of the protein BDNF than the Val form (Bath \& } \\
\text { Lee, 2006) }\end{array}$ \\
\hline $\begin{array}{l}\text { HPA axis } \\
\text { CRHR1 }\end{array}$ & $\begin{array}{l}\text { The CRHR1 gene encodes a G protein-coupled receptor that binds } \\
\text { neuropeptides of the corticotropin-releasing hormone family, which } \\
\text { play a major role in regulating the HPA pathway (National Center for } \\
\text { Biotechnology Information, 2016a). Resilience has been associated } \\
\text { with the brain's ability to moderate stress-induced increases in cortisol } \\
\text { and the corticotropin-releasing hormone in the HPA axis (Osorio et } \\
\text { al., 2016). }\end{array}$ \\
\hline $\begin{array}{l}\text { Others influencing CNS } \\
\text { OXTR }\end{array}$ & $\begin{array}{l}\text { The OXTR gene encodes a protein that belongs to the G-protein- } \\
\text { coupled receptor family and acts as a receptor for oxytocin (National } \\
\text { Center for Biotechnology Information, 2016b). A metaanalysis re- } \\
\text { vealed that G allele homozygotes of a SNP, rs53576, had higher gen- } \\
\text { eral sociality than the A allele carriers (Li et al., 2015). Although the } \\
\text { genetic function of rs53576 is not known, an fMRI study found the } \\
\text { A-allele carriers of rs53576 in OXTR showed a significant decrease in } \\
\text { hypothalamus gray matter compared to G allele homozygotes (Tost et } \\
\text { al., 2010). }\end{array}$ \\
\hline RGS2 & $\begin{array}{l}\text { The RGS2 gene encodes the regulator of G-protein signaling } 2 \text { (RGS2) } \\
\text { protein, which modulates neurotransmitter response by accelerating } \\
\text { the deactivation of G-proteins (National Center for Biotechnology In- } \\
\text { formation, 2016c). RGS2 is highly expressed in regions of the human } \\
\text { brain, such as the hippocampus, amygdala, and hypothalamus (Neubig } \\
\text { \& Siderovski, 2002), that are involved in anxiety and fear processing } \\
\text { (Stahl, 2013). Variation in rs } 4606 \text { in RGS2 is associated with variation } \\
\text { in RGS2 mRNA expression such that the G allele is associated with } \\
\text { low RGS2 expression compared to the C allele (Semplicini et al., 2006). }\end{array}$ \\
\hline
\end{tabular}

Note: $\mathrm{BDNF}=$ brain-derived neurotrophic factor; CRHR1 = corticotropin-releasing hormone receptor 1; CNS = central nervous system; DRD4 = dopamine receptor D4; $\mathrm{fMRI}=$ functional magnetic resonance imaging; $\mathrm{HPA}=$ hypothalamic-pituitary-adrenal; $\mathrm{mRNA}=$ messenger RNA; OXTR = oxytocin receptor; $\mathrm{RGS2}$ = regulator of G-protein signaling 2; SNP = single-nucleotide polymorphisms 


\section{5-HTTLPR}

Three serotonin transporter genotypes in 5-HTTLPR affect receptor activity: long/long (L/L), long/short (L/S), and short/short (S/S; Heils et al., 1996). There is also an additional single-base substitution (A > G) in the L form of 5-HTTLPR identified as rs25531 (Hu et al., 2006) and designated by an apostrophe ('). The variation in rs25531, LG variant, is a functional equivalent of the $S$ variant of 5-HTTLPR (Hu et al., 2006; Wendland, Martin, Kruse, Lesch, \& Murphy, 2006). The entire range of genotypes for 5-HTTLPR and rs25531 can be reclassified as $\mathrm{L}^{\prime} / \mathrm{L}^{\prime}=\mathrm{LA} / \mathrm{LA}_{A} \mathrm{~L}^{\prime} / \mathrm{S}^{\prime}=\mathrm{LA} / \mathrm{S}$ and $\mathrm{LA}_{\mathrm{A}} / \mathrm{LG}$; and $\mathrm{S}^{\prime} / \mathrm{S}^{\prime}=\mathrm{S} / \mathrm{S}$ and $\mathrm{LG} / \mathrm{S}$ and $\mathrm{LG} / \mathrm{Lg}$ (Parsey et al., 2006). Some investigators genotyped rs25531 and reclassified the results based on the level of expression, and others did not.

There were six $G \times E$ interaction studies that genotyped 5-HTTLPR and rs25531 and measured positive mental health outcomes (Table 3). Of these, three found that individuals with the L/L or L'/L' genotype of 5-HTTLPR and rs25531 maintained positive mental health despite exposure to adversity. In contrast, the other three studies found that individuals with the $S / S$ or $S^{\prime} / S^{\prime}$ genotype maintained positive mental health despite exposure to adversity.

Table 3. Genetic Variants Associated with Psychological Resilience and Number of Supporting Studies Reviewed

\begin{tabular}{|c|c|c|}
\hline Genotype Contributing to Psychological Resilience & \# of Studies & Author (Year) \\
\hline \multicolumn{3}{|l|}{ 5-HTTLPR and rs25531 } \\
\hline $\mathrm{L} / \mathrm{L}$ or $\mathrm{L}^{\prime} / \mathrm{L}^{\prime}$ & $n=3$ & $\begin{array}{r}\text { Cicchetti \& Rogosch (2012), Nederhof } \\
\text { et al. (2010), and Nikolova et al. (2012) }\end{array}$ \\
\hline$S / S$ or $S^{\prime} / S^{\prime}$ & $n=3$ & $\begin{array}{l}\text { Carli et al. (2011), Graham et al. (2013), } \\
\text { and Reinelt et al. (2015) }\end{array}$ \\
\hline \multicolumn{3}{|l|}{ DRD4 } \\
\hline $\mathrm{C} / \mathrm{C}$ and $\mathrm{C} / \mathrm{T}$ of rs 1800955 & $n=1$ & Cicchetti and Rogosch (2012) \\
\hline $\begin{array}{l}\text { 7r/7r and } 4 r / 7 r \text { of VNTR (a 7-repeat variant } \\
\text { in exon III) }\end{array}$ & $n=1$ & Das et al. (2011) \\
\hline \multicolumn{3}{|l|}{$B D N F$} \\
\hline $\mathrm{Val} / \mathrm{Val}$ of rs6265 & $n=2$ & $\begin{array}{l}\text { Nederhof et al. (2010), and van Winkel } \\
\text { et al. (2014) }\end{array}$ \\
\hline \multicolumn{3}{|l|}{ CRHR1 } \\
\hline $\begin{array}{l}\text { One or } 2 \text { copies of TAT haplotypes of rs110402, } \\
\text { rs } 242924 \text {, and rs7209436 }\end{array}$ & $n=1$ & Cicchetti and Rogosch (2012) \\
\hline \multicolumn{3}{|l|}{ OXTR } \\
\hline $\mathrm{G} / \mathrm{G}$ of $\mathrm{rs} 53576$ & $n=1$ & Cicchetti and Rogosch (2012) \\
\hline $\mathrm{A} / \mathrm{A}$ of $\mathrm{rs} 53576$ & $n=1$ & Bradley et al. (2013) \\
\hline \multicolumn{3}{|l|}{ RGS2 } \\
\hline G/G of rs4606 & $n=1$ & Dunn et al. (2014) \\
\hline
\end{tabular}

Note: BDNF = brain-derived neurotrophic factor; CRHR1 = corticotropin-releasing hormone receptor 1; DRD4 = dopamine receptor D4; 5-HTTLPR = serotonin-transporter-linked polymorphic region; RGS2 = regulator of G-protein signaling 2; VNTR = variable number tandem repeat. 
DRD4

The DRD4 gene codes for the dopamine $\mathrm{D} 4$ receptor, which is responsible for neuronal signaling regulating emotions and complex behaviors (Wu et al., 2013). In the present systematic review, we found two studies reporting significant interactions between genetic variations in $D R D 4$ and the environment. Each of these studies investigated different kinds of polymorphisms in DRD4. Cicchetti and Rogosch (2012) genotyped for a SNP, rs1800955, in DRD4. Das, Cherbuin, Tan, Anstey, and Easteal (2011) investigated a 7-repeat variant in exon III in $D R D 4$, another type of genetic variation known as variable number tandem repeat (VNTR).

Cicchetti and Rogosch (2012) found that children with the cytosine/cytosine (C/C) and cytosine/thymine (C/T) genotypes of rs1800955 in DRD4 had higher scores on measurements of resilient functioning regardless of maltreatment status. Das et al. (2011) found that individuals in the general population with the $7 \mathrm{r} / 7 \mathrm{r}$ and $4 \mathrm{r} / 7 \mathrm{r}$ genotypes of VNTR in DRD4 exon III maintained higher resilience scores regardless of exposure to childhood adversity when compared to those with the $4 \mathrm{r} / 4 \mathrm{r}$ genotype. These findings suggest that the $\mathrm{C} / \mathrm{C}$ and $\mathrm{C} / \mathrm{T}$ genotypes of rs1800955 and the $7 \mathrm{r} / 7 \mathrm{r}$ and $4 \mathrm{r} / 7 \mathrm{r}$ genotypes of VNTR in DRD4 contribute to resilience (Table 3).

$B D N F$

The BDNF gene contains a SNP, rs6265, that produces an amino acid substitution that changes valine (Val) to methionine (Met) and has three genotype variations: $\mathrm{Val} / \mathrm{Val}, \mathrm{Val} / \mathrm{Met}$, and Met/Met (National Center for Biotechnology Information, 2017a). Both Nederhof et al. (2010) and van Winkel et al. (2014) found that individuals with the Val/Val genotype of rs6265 in $B D N F$ maintained positive mental health when exposed to negative stimuli. In contrast, those with the Val/Met and Met/Met genotypes were more affected by adversity. These findings suggest that the Val/Val genotype of rs6265 in BDNF contributes to resilience (Table 3).

CRHR1

CRHR1 is a gene encoding a G-protein receptor that binds neuropeptides of the corticotropinreleasing hormone (National Center for Biotechnology Information, 2016a). Cicchetti and Rogosch (2012) investigated three strongly related SNPs in CRHR1, rs7209436 (T to C), rs110402 (A to G), and rs242924 ( $\mathrm{T}$ to $\mathrm{G}$ ) and found that children with one or two copies of the thymine/adenine/thymine (TAT) combination of these SNPs (i.e., haplotype) in CRHR1 maintained higher scores on measures indicating resilient functioning independent of maltreatment status. These findings suggest that one or two copies of the TAT combination in CRHR1 also provide some level of biological resilience (Table 3).

OXTR

The OXTR gene encodes a protein from the G-protein receptor family acting for oxytocin (National Center for Biotechnology Information, 2016b). The rs53576 SNP in OXTR reflects a guanine $(G)$ to adenine $(A)$ change, producing three genotypes: $A / A, A / G$, and $G / G$. Two studies that measured positive mental health outcomes reported significant interactions between rs53576 in OXTR and environment (Table 3). Cicchetti and Rogosch (2012) found 
that the impact of maltreatment adversity on mental health was less in children with the G/G genotype of rs53576 in OXTR when compared to those with the A/A and A/G genotypes. Bradley, Davis, Wingo, Mercer, and Ressler (2013) reported that adults with the A/A genotype of rs53576 in OXTR maintained positive affect and resilient coping scores regardless of the family environment. In contrast, adults with the $G / G$ and $A / G$ genotypes were more influenced by the family environment, both positively and negatively. Cicchetti and Rogosch (2012) findings suggest that the G/G genotype of rs53576 in OXTR contributes to resilience, whereas Bradley et al.'s (2013) findings indicate that the A/A genotype contributed to resilience (Table 3).

RGS2

The RGS2 gene encodes the RGS2 protein, which modulates that the rate of deactivation of $\mathrm{G}$ proteins, thereby controlling neurotransmitter responses (National Center for Biotechnology Information, 2016c). Dunn et al. (2014) investigated rs4606 in RGS2 producing three genotypes: C/C, C/G, and G/G. These investigators reported that the PTG scores increased among Black parents with the G/G genotype of rs4606 in RGS2 exposed to Hurricane Katrina. Because Dunn et al. (2014) found that positive mental health (i.e., PTG) among individuals with the G/G genotype improved as the severity of adversity increased, they identified the G/G genotype of rs4606 in RGS2 as contributing to resilience (Table 3).

\section{Discussion}

This systematic review of $10 \mathrm{G} \times \mathrm{E}$ interaction studies revealed six genes that are empirically associated with psychological resilience: 5-HTTLPR, DRD4, BDNF, CRHR1, OXTR, and RGS2. Given that there are approximately 19,000 human protein-coding genes (Ezkurdia et al., 2014), it is certainly possible that most of the genes contributing to psychological resilience have not yet been tested. Additionally, consideration of the literature investigating interactions between genetic predispositions and environmental factors contributing to complex behavioral outcomes requires a degree of caution (Dick et al., 2015).

Among these six genetic variants, 5-HTTLPR and rs25531 were the most frequently investigated polymorphism, with six studies examining associations. Of these, three identified the $\mathrm{L} / \mathrm{L}$ or $\mathrm{L}^{\prime} / \mathrm{L}^{\prime}$ genotype of 5-HTTLPR and rs25531 as contributing to resilience, whereas the other three studies suggested that the $S / S$ or $S^{\prime} / S^{\prime}$ genotype contributed to resilience. Study population and sample size varied among these six studies. All three of the studies that found that the $\mathrm{L} / \mathrm{L}$ or $\mathrm{L}^{\prime} / \mathrm{L}^{\prime}$ genotype of 5HTTLPR and rs25531 contributed to resilience investigated children/adolescents. In contrast, the other three studies, which found the $\mathrm{S} / \mathrm{S}$ or $\mathrm{S}^{\prime} / \mathrm{S}^{\prime}$ genotype of 5-HTTLPR and rs25531 contributed to resilience, investigated adults. $\mathrm{O}^{\prime}$ Hara et al. (2012) suggested that the negative impact of the $S$ form of 5-HTTLPR on stress-related outcomes may be attenuated with increased age as individuals process more positive information and exclude more negatively associated content. However, readers should use caution when considering this interpretation because evidence of an Age $\times$ Genotype Effect is scarce.

The studies we selected for the present review differed in the assumptions they used for statistical analysis, which affects the comparability and interpretation of the results. Some 
investigators genotyped for 5-HTTLPR and rs25531 and reclassified the genotypes based on the level of expression, and others did not. The general recommendation is to genotype for rs25531 and reclassify the genotypes based on transcriptional functionality (Murphy, Maile, \& Vogt, 2013; Parsey et al., 2006). About $20 \%$ of Caucasians, for example, carry the $\mathrm{LA}_{\mathrm{A}} / \mathrm{Lg}_{\mathrm{g}}$ genotype of 5-HTTLPR and rs25531 (Murphy \& Moya, 2011). The LA/Lg genotype, however, should be categorized as the L'/S' genotype instead of the L/L genotype (Murphy \& Moya, 2011). Inclusion of genotyping for rs25531 may influence the results of statistical analyses. For example, Stein, Campbell-Sills, and Gelernter (2009) found significant associations between resilience scores and 5-HTTLPR but not with the 5-HTTLPR and rs25531 triallelic classification system. The present systematic review suggests that age/developmental factors and rs25531 reclassification may contribute to the complexity of genetic influence on psychological reactions after exposure to stressful events.

The rs6265 SNP in BDNF appeared in two of the studies we reviewed. The allele frequencies of rs6265 in BDNF differ by ethnicity/race. For example, the Met variant is rare among Caucasians (25-32\%) but is more common among Asians (40-50\%; Verhagen et al., 2010). Both Nederhof et al. (2010) and van Winkel et al. (2014), who reported the Val/Val genotype of rs6265 in BDNF as contributing to resilience, investigated European populations: Dutch (Nederhof et al., 2010) and Belgian (van Winkel et al., 2014). If their populations were non-Caucasian (e.g., Asians), their findings might have been different, indicating that ethnicity/race is another factor contributing to the complexity of genetic influence on resilience.

The findings regarding rs53576 in OXTR are complicated by the multiple methods researchers used to analyze the heterozygous status (i.e., G/A genotype). Cicchetti and Rogosch (2012) reported that the G/G genotype was associated with resilience, whereas Bradley et al. (2013) suggested that the A/A genotype contributed to resilience. Within the analysis of the data, Cicchetti and Rogosch (2012) combined the A/A and A/G genotypes (i.e., $A / A$ and $A / G$ vs. G/G), whereas Bradley et al. (2013) grouped the $G / G$ and $A / G$ genotypes together (i.e., A/A vs. A/G and G/G) for statistical analyses. This practice provides different outcomes, as Cicchetti and Rogosch (2012) assumed the dominant effect of the A variant, whereas Bradley et al. (2013) assumed the dominant effect of the G variant. The combination of the heterozygote with a homozygote was inconsistent across studies for OXTR and other polymorphisms. The different assumptions regarding the mode of inheritance used in statistical analyses across studies obscure the complexity of the underlying genetic model (Dick et al., 2015). For example, although there is biological evidence supporting the dominant effect of the $S$ variant of 5-HTTLPR (Lesch et al., 1996), the genetic function of rs53576 is not known.

This systematic review also reveals three issues that are contributing to the complexity of the impact of genetic influence on resilience. First, sex may play an important role because gonadal steroids, such as testosterone and estrogen, also contribute to resilience (Charney, 2004). Some of the investigations, such as Carli et al. (2011), included only male participants. The findings of this and similar studies are not generalizable without inclusion of female participants. Second, the sample sizes of the studies varied widely, from $N=70$ (Nikolova, Bogdan, \& Pizzagalli, 2012) to $N=1,811$ (Reinelt et al., 2015). A sample 
size of less than 1,000 may be underpowered for candidate gene association studies to detect genetic influences (Dick et al., 2015). Third, in addition to $G \times E$ interactions, other forms of genetic influence, such as epistasis ( $G \times G$ interactions) and epigenetic changes in chromatin structure, contribute to resilience (Feder et al., 2009), requiring further exploration. To partially address the effects of multiple genetic variations, Cicchetti and Rogosch (2012), who investigated four genetic variants, constructed a polygenic susceptibility score.

This systematic review has some limitations. First, although animal studies and epigenetic studies are also critically important for examining the complex mechanism of resilience (Feder et al., 2009; Franklin, Saab, \& Mansuy, 2012), we excluded them from the review as the focus was on human responses influenced by genetic variations. Second, we included only $\mathrm{G} \times \mathrm{E}$ interaction studies measuring positive mental health responses to adversity. An alternative operationalization of resilience is to examine the range of no response to mild psychopathological symptoms following adverse experiences (Niitsu et al., 2017), but we did not include studies that did so. Third, because of the limited numbers of available studies, we did not restrict inclusion based on severity, duration, or type of stressor. For example, stressors ranged from mild (e.g., school final examinations) to severe (e.g., childhood adversity). Findings with rs4606 in RGS2 and PTG may thus be more relevant to the context of natural disasters (Dunn et al., 2014). The type of stressor and the effects of multiple stressors need to be considered more carefully for future studies. Additionally, a cross-sectional study cannot determine the changes in genetic impact on resilience over time. Fourth, we applied no statistical methods, such as funnel plots, to assess the risk of bias, which is a recommended practice for systematic reviews and meta-analyses (Liberati et al., 2009). The intention of this review was to systematically identify candidate genes associated with resilience. Considering that all 10 studies we reviewed reported positive findings, study publication bias and outcome reporting bias are possible.

Nurse scientists have been investigating psychological resilience for decades (e.g., Wagnild \& Young, 1993), in accordance with nursing's holistic view of health (Szanton \& Gill, 2010). With recent advances in genetic and genomic science, nurse scientists can incorporate genetics/genomics into research trajectories (Alexander, 2017). By increasing nursing research on promoting the health of individuals based on genomic information, nurses aim to enhance personalized nursing care for all individuals and populations (Williams et al., 2016). We hope this systematic review serves as a starting point for facilitating interdisciplinary investigations of the genetic influence on psychological resilience. Based on this review, we recommend studies of genetic variants involved with the central nervous system and HPA axis, including 5-HTTLPR, DRD4, BDNF, CRHR1, OXTR, and RGS2, to investigate genetic influence on resilience. Furthermore, genes regulating other neurotransmitters (e.g., neuropeptide $\mathrm{Y}$ ) and hormones (e.g., allopregnanolone) may also be strong candidate genes for playing a role in resilience (Osorio et al., 2016).

\section{Conclusion}

In the present review, we found that six genes were empirically associated with psychological resilience. The $\mathrm{L} / \mathrm{L}$ or $\mathrm{L}^{\prime} / \mathrm{L}^{\prime}$ genotype of 5-HTTLPR and rs25531 was identified as 
contributing to resilience in children/adolescents, whereas the $S / S$ or $S^{\prime} / S^{\prime}$ genotype contributed to resilience in adults. In addition, the Val/Val genotype of rs6265 in BDNF was identified as contributing to a resilient response among Caucasians. There are numerous factors contributing to the difficulty of untangling the complexity of genetic influence on resilience, including analysis of rs25531 classification, assumptions about the mode of inheritance, operationalization of resilience, demographic and population characteristics, sample size, and other types of genetic influence including epistasis and epigenetics. We hope that this systematic review will serve as a useful starting place in an area in need of much further investigation.

Author Contributions - K. Niitsu contributed to conception, design, acquisition, analysis, and interpretation; drafted and critically revised the manuscript; gave final approval; and agrees to be accountable for all aspects of work ensuring integrity and accuracy. M. Rice contributed to conception, design, and analysis; critically revised the manuscript; gave final approval; and agrees to be accountable for all aspects of work ensuring integrity and accuracy. J. Houfek contributed to conception, design, and analysis; critically revised the manuscript; gave final approval; and agrees to be accountable for all aspects of work ensuring integrity and accuracy. S. Stoltenberg contributed to conception; critically revised the manuscript; gave final approval; and agrees to be accountable for all aspects of work ensuring integrity and accuracy. K. Kupzyk contributed to conception; critically revised the manuscript; gave final approval; and agrees to be accountable for all aspects of work ensuring integrity and accuracy. C. Barron contributed to conception; critically revised the manuscript; gave final approval; and agrees to be accountable for all aspects of work ensuring integrity and accuracy.

Declaration of Conflicting Interests - The authors declare no potential conflicts of interest with respect to the research, authorship, and/or publication of this article.

Funding - This article was partially supported by grants from the American Psychiatric Nurses Association, the International Society of Nurses in Genetics, the Sigma Theta Tau International Gamma Pi Chapter, and the University of Colorado Endowment for Psychiatric Mental Health Nursing.

\section{References}

Alexander, S. A. (2017). Announcing the primer in genetics and genomics series. Biological Research for Nursing, 19, 5-6. doi: 10. 1177/1099800416677094

Almedom, A. M., \& Glandon, D. (2007). Resilience is not the absence of PTSD any more than health is the absence of disease. Journal of Loss and Trauma, 12, 127-143.

American Psychiatric Association. (2013). Diagnostic and statistical manual of mental disorders (5th ed.). Arlington, VA: Author.

Asghari, V., Sanyal, S., Buchwaldt, S., Paterson, A., Jovanovic, V., \& Van Tol, H. H. (1995). Modulation of intracellular cyclic AMP levels by different human dopamine D4 receptor variants. Journal of Neurochemistry, 65, 1157-1165.

Bath, K. G., \& Lee, F. S. (2006). Variant BDNF (Val66Met) impact on brain structure and function. Cognitive, Affective, \& Behavioral Neuroscience, 6, 79-85.

Benjet, C., Bromet, E., Karam, E. G., Kessler, R. C., McLaughlin, K. A., Ruscio, A. M., . . Koenen, K. C. (2016). The epidemiology of traumatic event exposure worldwide: Results from the world 
mental health survey consortium. Psychological Medicine, 46, 327-343. doi: 10.1017/S003329171 5001981

Bonanno, G. A. (2012). Uses and abuses of the resilience construct: Loss, trauma, and health-related adversities. Social Science and Medicine, 74, 753-756. doi: 10.1016/j.socscimed.2011.11.022

Bonanno, G. A., \& Diminich, E. D. (2013). Annual research review: Positive adjustment to adversity Trajectories of minimal-impact resilience and emergent resilience. Journal of Child Psychology and Psychiatry, 54, 378-401. doi: 10.1111/jcpp.12021

Bonanno, G. A., Galea, S., Bucciarelli, A., \& Vlahov, D. (2007). What predicts psychological resilience after disaster? The role of demographics, resources, and life stress. Journal of Consulting and Clinical Psychology, 75, 671-682. doi: 10.1037/0022-006X.75.5.671

Bradley, B., Davis, T. A., Wingo, A. P., Mercer, K. B., \& Ressler, K. J. (2013). Family environment and adult resilience: Contributions of positive parenting and the oxytocin receptor gene. European Journal of Psychotraumatology, 4, 21659. doi: 10.3402/ejpt.v4i0. 21659

Canli, T., \& Lesch, K. P. (2007). Long story short: The serotonin transporter in emotion regulation and social cognition. Nature Neuroscience, 10, 1103-1109. doi: 10.1038/nn1964

Carli, V., Mandelli, L., Zaninotto, L., Roy, A., Recchia, L., Stoppia, L., . . Serretti, A. (2011). A protective genetic variant for adverse environments? The role of childhood traumas and serotonin transporter gene on resilience and depressive severity in a high-risk population. European Psychiatry, 26, 471-478. doi: 10. 1016/j.eurpsy.2011.04.008

Caspi, A., \& Moffitt, T. E. (2006). Gene-environment interactions in psychiatry: Joining forces with neuroscience. Nature Reviews Neuroscience, 7, 583-590. doi: 10.1038/nrn1925

Charney, D. S. (2004). Psychobiological mechanisms of resilience and vulnerability: Implications for successful adaptation to extreme stress. American Journal of Psychiatry, 161, 195-216.

Cicchetti, D. (2010). Resilience under conditions of extreme stress: A multilevel perspective. World Psychiatry, 9, 145-154.

Cicchetti, D., \& Rogosch, F. A. (2012). Gene $\times$ Environment interaction and resilience: Effects of child maltreatment and serotonin, corticotropin releasing hormone, dopamine, and oxytocin genes. Development and Psychopathology, 24, 411-427. doi: 10.1017/ S0954579412000077

Connor, K. M., \& Davidson, J. R. (2003). Development of a new resilience scale: The ConnorDavidson Resilience Scale (CDRISC). Depression and Anxiety, 18, 76-82.

Das, D., Cherbuin, N., Tan, X., Anstey, K. J., \& Easteal, S. (2011). DRD4-exonIII-VNTR moderates the effect of childhood adversities on emotional resilience in young-adults. PLoS One, 6, e20177. doi: 10.1371/journal.pone.0020177

Davydov, D. M., Stewart, R., Ritchie, K., \& Chaudieu, I. (2010). Resilience and mental health. Clinical Psychology Review, 30, 479-495. doi: 10.1016/j.cpr.2010.03.003

Dick, D. M., Agrawal, A., Keller, M. C., Adkins, A., Aliev, F., Monroe, S., . . Sher, K. J. (2015). Candidate gene-environment interaction research: Reflections and recommendations. Perspectives on Psychological Science, 10, 37-59. doi: 10.1177/ 1745691614556682

Dunn, E. C., Solovieff, N., Lowe, S. R., Gallagher, P. J., Chaponis, J., Rosand, J., . . Smoller, J. W. (2014). Interaction between genetic variants and exposure to Hurricane Katrina on post-traumatic stress and post-traumatic growth: A prospective analysis of low income adults. Journal of Affective Disorders, 152-154, 243-249. doi: 10. 1016/j.jad.2013.09.018

Ezkurdia, I., Juan, D., Rodriguez, J. M., Frankish, A., Diekhans, M., Harrow, J., . . Tress, M. L. (2014). Multiple evidence strands suggest that there may be as few as 19,000 human protein-coding genes. Human Molecular Genetics, 23, 5866-5878. doi: 10.1093/hmg/ddu309 
Feder, A., Nestler, E. J., \& Charney, D. S. (2009). Psychobiology and molecular genetics of resilience. Nature Reviews Neuroscience, 10, 446-457. doi: 10.1038/nrn2649

Franklin, T. B., Saab, B. J., \& Mansuy, I. M. (2012). Neural mechanisms of stress resilience and vulnerability. Neuron, 75, 747-761. doi: 10.1016/j.neuron.2012.08.016

Graham, D. P., Helmer, D. A., Harding, M. J., Kosten, T. R., Petersen, N. J., \& Nielsen, D. A. (2013). Serotonin transporter genotype and mild traumatic brain injury independently influence resilience and perception of limitations in veterans. Journal of Psychiatric Research, 47, 835-842.

Heils, A., Teufel, A., Petri, S., Stober, G., Riederer, P., Bengel, D., \& Lesch, K. P. (1996). Allelic variation of human serotonin transporter gene expression. Journal of Neurochemistry, 66, 2621-2624.

Hu, X. Z., Lipsky, R. H., Zhu, G., Akhtar, L. A., Taubman, J., Greenberg, B. D., . . Goldman, D. (2006). Serotonin transporter promoter gain-of-function genotypes are linked to obsessive-compulsive disorder. American Journal of Human Genetics, 78, 815-826. doi: 10.1086/503850

Jovanovic, V., Guan, H. C., \& Van Tol, H. H. (1999). Comparative pharmacological and functional analysis of the human dopamine D4.2 and D4.10 receptor variants. Pharmacogenetics, 9, 561-568.

Karam, E. G., Friedman, M. J., Hill, E. D., Kessler, R. C., McLaughlin, K. A., Petukhova, M., . . . Koenen, K. C. (2014). Cumulative traumas and risk thresholds: 12-month PTSD in the World Mental Health (WMH) surveys. Depression and Anxiety, 31, 130-142. doi: 10.1002/da.22169

Kim-Cohen, J., \& Turkewitz, R. (2012). Resilience and measured gene-environment interactions. Development and Psychopathology, 24, 1297-1306. doi: 10.1017/S0954579412000715

Lesch, K. P., Bengel, D., Heils, A., Sabol, S. Z., Greenberg, B. D., Petri, S., . . Murphy, D. L. (1996). Association of anxiety-related traits with a polymorphism in the serotonin transporter gene regulatory region. Science, 274, 1527-1531.

Li, J., Zhao, Y., Li, R., Broster, L. S., Zhou, C., \& Yang, S. (2015). Association of oxytocin receptor gene (OXTR) rs53576 polymorphism with sociality: A meta-analysis. PLoS One, 10, e0131820. doi: 10.1371/journal.pone.0131820

Liberati, A., Altman, D. G., Tetzlaff, J., Mulrow, C., Gotzsche, P. C., Ioannidis, J. P., . . Moher, D. (2009). The PRISMA statement for reporting systematic reviews and meta-analyses of studies that evaluate healthcare interventions: Explanation and elaboration. British Medical Journal, 339, b2700. doi: 10.1136/bmj.b2700

Luthar, S. S., Cicchetti, D., \& Becker, B. (2000). The construct of resilience: A critical evaluation and guidelines for future work. Child Development, 71, 543-562.

Mancini, A. D., \& Bonanno, G. A. (2010). Resilience to potential trauma: Toward a lifespan approach. In J. W. Reich, A. J. Zautra, \& J. S. Hall (Eds.), Handbook of adult resilience (pp. 258-280). New York, NY: Guilford Press.

Moher, D., Liberati, A., Tetzlaff, J., \& Altman, D. G.; PRISMA Group. (2009). Preferred reporting items for systematic reviews and meta-analyses: The PRISMA statement. PLoS Medicine, 6, e1000097. doi: 10.1371/journal.pmed.1000097

Murphy, D. L., Maile, M. S., \& Vogt, N. M. (2013). 5HTTLPR: White knight or dark blight? ACS Chemical Neuroscience, 4, 13-15. doi: 10.1021/cn3002224

Murphy, D. L., \& Moya, P. R. (2011). Human serotonin transporter gene (SLC6A4) variants: Their contributions to understanding pharmacogenomic and other functional $G \times G$ and $G \times E$ differences in health and disease. Current Opinion in Pharmacology, 11, 3-10.

Murray, A. M., Hyde, T. M., Knable, M. B., Herman, M. M., Bigelow, L. B., Carter, J. M., ... Kleinman, J. E. (1995). Distribution of putative D4 dopamine receptors in postmortem striatum from patients with schizophrenia. Journal of Neuroscience, 15, 2186-2191. 
National Center for Biotechnology Information. (2016a). CRHR1 corticotropin releasing hormone receptor 1 [Homo sapiens (human)]. Retrieved from https://www.ncbi.nlm.nih.gov/gene?cmd=Retrieve \&dopt=Graphics\&list_uids=1394

National Center for Biotechnology Information. (2016b). OXTR oxytocin receptor [Homo sapiens (human)]. Retrieved from https://www.ncbi.nlm.nih.gov/gene?cmd=Retrieve\&dopt=Graphics\& list_uids $=5021$

National Center for Biotechnology Information. (2016c). RGS2 regulator of G-protein signaling 2 [Homo sapiens (human)]. Retrieved from https://www.ncbi.nlm.nih.gov/gene?cmd=Retrieve\&dopt=Graphics \&list_uids=5997

National Center for Biotechnology Information. (2017a). BDNF brain derived neurotrophic factor [Homo sapiens (human)]. Retrieved from https://www.ncbi.nlm.nih.gov/gene?cmd=Retrieve\&dopt=Graphics \&list_uids $=627$

National Center for Biotechnology Information. (2017b). Reference SNP (refSNP) cluster report: rs1800955. Retrieved from https://www.ncbi.nlm.nih.gov/projects/SNP/snp_ref.cgi?rs=1800955

National Center for Biotechnology Information. (2017c). SLC6A4 solute carrier family 6 member 4 [Homo sapiens (human)]. Retrieved from https://www.ncbi.nlm.nih.gov/gene/6532

Nederhof, E., Bouma, E. M., Riese, H., Laceulle, O. M., Ormel, J., \& Oldehinkel, A. J. (2010). Evidence for plasticity genotypes in a gene-gene-environment interaction: The TRAILS study. Genes, Brain and Behavior, 9, 968-973.

Neubig, R. R., \& Siderovski, D. P. (2002). Regulators of G-protein signalling as new central nervous system drug targets. Nature Reviews Drug Discovery, 1, 187-197.

Niitsu, K., Houfek, J. F., Barron, C. R., Stoltenberg, S. F., Kupzyk, K. A., \& Rice, M. J. (2017). A concept analysis of resilience integrating genetics. Issues in Mental Health Nursing, 38, 896-906.

Nikolova, Y., Bogdan, R., \& Pizzagalli, D. A. (2012). Perception of a naturalistic stressor interacts with 5-HTTLPR/rs25531 genotype and gender to impact reward responsiveness. Neuropsychobiology, 65, 45-54. doi: 10.1159/000329105

Oak, J. N., Oldenhof, J., \& Van Tol, H. H. (2000). The dopamine D(4) receptor: One decade of research. European Journal of Pharmacology, 405, 303-327.

O'Hara, R., Marcus, P., Thompson, W. K., Flournoy, J., Vahia, I., Lin, X., . . Jeste, D. V. (2012). 5HTTLPR short allele, resilience, and successful aging in older adults. American Journal of Geriatric Psychiatry, 20, 452-456.

Okuyama, Y., Ishiguro, H., Nankai, M., Shibuya, H., Watanabe, A., \& Arinami, T. (2000). Identification of a polymorphism in the promoter region of DRD4 associated with the human novelty seeking personality trait. Molecular Psychiatry, 5, 64-69.

Osorio, C., Probert, T., Jones, E., Young, A. H., \& Robbins, I. (2016). Adapting to stress: Understanding the neurobiology of resilience. Behavioral Medicine, 43, 307-322.

Pangallo, A., Zibarras, L., Lewis, R., \& Flaxman, P. (2015). Resilience through the lens of interactionism: A systematic review. Psychological Assessment, 27, 1-20.

Parsey, R., Hastings, R., Oquendo, M., Hu, X., Goldman, D., Huang, Y., . . Mann, J. (2006). Effect of a triallelic functional polymorphism of the serotonin-transporter-linked promoter region on expression of serotonin transporter in the human brain. American Journal of Psychiatry, 163, 48-51.

Plomin, R., Owen, M. J., \& McGuffin, P. (1994). The genetic basis of complex human behaviors. Science, 264, 1733-1739.

Pluess, M. (2017). Vantage sensitivity: Environmental sensitivity to positive experiences as a function of genetic differences. Journal of Personality, 85, 38-50. doi: 10.1111/jopy.12218 
Pluess, M., \& Meaney, M. J. (2015). Genes, environment, and psychological well-being. In M. Pluess (Ed.), Genetics of psychological well-being (pp. 251-265). Oxford, England: Oxford University Press.

Rana, B. K., Darst, B. F., Bloss, C., Shih, P. A., Depp, C., Nievergelt, C. M., . . Jeste, D. V. (2014). Candidate SNP associations of optimism and resilience in older adults: Exploratory study of 935 community-dwelling adults. American Journal of Geriatric Psychiatry, 22, 997-1006. doi: 10.1016/j.jagp .2014.03.009

Reinelt, E., Barnow, S., Stopsack, M., Aldinger, M., Schmidt, C., John, U., \& Grabe, H. (2015). Social support and the serotonin transporter genotype (5-HTTLPR) moderate levels of resilience, sense of coherence, and depression. American Journal of Medical Genetics, 168B, 383-391.

Rende, R. (2012). Behavioral resilience in the post-genomic era: Emerging models linking genes with environment. Frontiers in Human Neuroscience, 6, 50. doi: 10.3389/fnhum.2012.00050

Semplicini, A., Lenzini, L., Sartori, M., Papparella, I., Calo, L. A., Pagnin, E., ... Pessina, A. C. (2006). Reduced expression of Regulator of G-protein Signaling 2 (RGS2) in hypertensive patients increases calcium mobilization and ERK1/2 phosphorylation induced by angiotensin II. Journal of Hypertension, 24, 1115-1124. doi: 10.1097/01.hjh.0000226202.80689.8f

Southwick, S. M., Bonanno, G. A., Masten, A. S., Panter-Brick, C., \& Yehuda, R. (2014). Resilience definitions, theory, and challenges: Interdisciplinary perspectives. European Journal of Psychotraumatology, 5, 25338. doi: 10.3402/ejpt.v5.25338

Stahl, S. M. (2013). Stahl's essential psychopharmacology: Neuroscientific basis and practical applications (4th ed.). New York, NY: Cambridge University Press.

Stein, M. B., Campbell-Sills, L., \& Gelernter, J. (2009). Genetic variation in 5HTTLPR is associated with emotional resilience. American Journal of Medical Genetics Part B Neuropsychiatric Genetics, 150B, 900-906.

Szanton, S. L., \& Gill, J. M. (2010). Facilitating resilience using a society-to-cells framework: A theory of nursing essentials applied to research and practice. Advances in Nursing Science, 33, 329-343. doi: 10.1097/ANS.0b013e3181fb2ea2

Tedeschi, R. G., \& Calhoun, L. G. (1996). The Posttraumatic Growth Inventory: Measuring the positive legacy of trauma. Journal of Traumatic Stress, 9, 455-471.

Tedeschi, R. G., \& Calhoun, L. G. (2004). Posttraumatic growth: Conceptual foundations and empirical evidence. Psychological Inquiry, 15, 1-18. doi: 10.1207/s15327965pli1501_01

Tost, H., Kolachana, B., Hakimi, S., Lemaitre, H., Verchinski, B. A., Mattay, V. S., ... Meyer-Lindenberg, A. (2010). A common allele in the Oxytocin Receptor Gene (OXTR) impacts prosocial temperament and human hypothalamic-limbic structure and function. Proceedings of the National Academy of Sciences of the USA, 107, 13936-13941. doi: 10.1073/pnas.1003296107

van Winkel, M., Peeters, F., van Winkel, R., Kenis, G., Collip, D., Geschwind, N., . . Wichers, M. (2014). Impact of variation in the BDNF gene on social stress sensitivity and the buffering impact of positive emotions: Replication and extension of a gene-environment interaction. European Neuropsychopharmacology, 24, 930-938.

Verhagen, M., van der Meij, A., van Deurzen, P. A., Janzing, J. G., Arias-Vasquez, A., Buitelaar, J. K., \& Franke, B. (2010). Meta-analysis of the BDNF Val66Met polymorphism in major depressive disorder: Effects of gender and ethnicity. Molecular Psychiatry, 15, 260-271.

Wagnild, G. M., \& Young, H. M. (1993). Development and psychometric evaluation of the resilience scale. Journal of Nursing Measurement, 1, 165-178.

Walker, F. R., Pfingst, K., Carnevali, L., Sgoifo, A., \& Nalivaiko, E. (2017). In the search for integrative biomarker of resilience to psychological stress. Neuroscience and Biobehavioral Reviews, 74, 310-320. doi: 10.1016/j.neubiorev.2016.05.003 
Wendland, J. R., Martin, B. J., Kruse, M. R., Lesch, K. P., \& Murphy, D. L. (2006). Simultaneous genotyping of four functional loci of human SLC6A4, with a reappraisal of 5-HTTLPR and rs25531. Molecular Psychiatry, 11, 224-226. doi: 10.1038/sj.mp.4001789

Williams, J. K., Katapodi, M. C., Starkweather, A., Badzek, L., Cashion, A. K., Coleman, B., ... Hickey, K. T. (2016). Advanced nursing practice and research contributions to precision medicine. Nursing Outlook, 64, 117-123. doi: 10.1016/j.outlook.2015.11.009

Wu, G., Feder, A., Cohen, H., Kim, J. J., Calderon, S., Charney, D. S., \& Mathe, A. A. (2013). Understanding resilience. Frontiers in Behavioral Neuroscience, 7, 10. doi: 10.3389/fnbeh.2013.00010

Yehuda, R., Hoge, C. W., McFarlane, A. C., Vermetten, E., Lanius, R. A., Nievergelt, C. M., ... Hyman, S. E. (2015). Post-traumatic stress disorder. Nature Reviews Disease Primers, 1, 15057.

Yu, W., Clyne, M., Khoury, M. J., \& Gwinn, M. (2010). Phenopedia and genopedia: Disease-centered and gene-centered views of the evolving knowledge of human genetic associations. Bioinformatics, 26, 145-146. doi: 10.1093/bioinformatics/btp618

Zhao, M., Yang, J., Wang, W., Ma, J., Zhang, J., Zhao, X., . . Yang, Y. (2017). Meta-analysis of the interaction between serotonin transporter promoter variant, stress, and posttraumatic stress disorder. Scientific Reports, 7, 16532. doi: 10.1038/s41598-017-15168-0 